\title{
Correction: Seroprevalence of Borrelia burgdorferi sensu lato and Anaplasma phagocytophilum in Danish horses
}

\author{
Marie GB Hansen ${ }^{1,2}$, Mette Christoffersen², Line R Thuesen', Morten R Petersen², Anders M Bojesen ${ }^{1 *}$
}

\section{Correction}

After publication of this work [1] it has come to our attention that one of the references used in the article [2] has been incorrectly cited. The sentence "The seroprevalence of $A$. phagocytophilum in Europe varies from 83.3\% in Holland" in the second paragraph of the Background section of the article is incorrectly written and should state "The PCR detection of A. phagocytophilum in Europe varies from $9.8 \%$ in Holland" instead. The authors apologise for any confusion caused.

\footnotetext{
Author details

'Department of Veterinary Disease Biology, Faculty of Life Sciences, University of Copenhagen, Stigbøjlen 4, DK-1870 Frederiksberg C, Denmark. ${ }^{2}$ Department of Large Animal Sciences, Faculty of Life Sciences, University of Copenhagen, Dyrlægevej 68, DK-1870 Frederiksberg C, Denmark.
}

Received: 18 August 2010 Accepted: 18 August 2010

Published: 18 August 2010

\section{References}

1. Hansen MGB, Christoffersen M, Thuesen LR, Petersen MR, Bojesen AM: Seroprevalence of Borrelia burgdorferi sensu lato and Anaplasma phagocytophilum in Danish horses. Acta Veterinaria Scandinavica 2010, 52:3.

2. Butler CM, Nijhof AM, Jongejan F, Kolk JH: Anaplasma phagocytophilum infection in horses in the Netherlands. Vet Rec 2008, 162:216-217.

\footnotetext{
* Correspondence: miki@life.ku.dk

'Department of Veterinary Disease Biology, Faculty of Life Sciences, University of Copenhagen, Stigbøjlen 4, DK-1870 Frederiksberg C, Denmark
}

Full list of author information is available at the end of the article

Submit your next manuscript to BioMed Central and take full advantage of:

- Convenient online submission

- Thorough peer review

- No space constraints or color figure charges

- Immediate publication on acceptance

- Inclusion in PubMed, CAS, Scopus and Google Scholar

- Research which is freely available for redistribution

Submit your manuscript at www.biomedcentral.com/submit
() Biomed Central 